\title{
Pulmonary metastasis of transmissible venereal tumour in a dog: a case report
}

\section{Metastase pulmonar de tumor venéreo transmissível em um cão: relato de caso}

\author{
Fernanda de Lima Correa ${ }^{*} \oplus$, Luciana Wolfran ${ }^{1} \oplus$, Aline de Marco Viott ${ }^{1} \oplus$, \\ Juliana das Chagas Goulart ${ }^{\circledR}$, Flávio Shigueru Jojima ${ }^{\oplus}$, Paula Agostini ${ }^{\circledR}$
}

\begin{abstract}
The transmissible venereal tumour (TVT) is one of the most frequent neoplasias in dogs. This tumour has specific characteristics, and it is exclusively of canines. Its transmission occurs through viable neoplastic cell transplantation when in contact with mucosa or unhealthy skin and rarely metastasise. This paper aims to report a rare presentation of pulmonary metastasis of widespread transmissible venereal tumours in a Blue Heeler dog. The patient was cachectic, dyspnoeic, and dehydrated and had multiple skin and pharynx nodulations. The cytology of all cutaneous nodulations showed round vacuolated cells with large eccentric nuclei and loose chromatin, which is compatible with TVT's microscopic characteristics. Owing to the clinical evolution and reserved prognosis, the patient was euthanized. Necroscopy revealed a mass in the right pulmonary caudal lobe. The mass showed the same histopathologic characteristic of the others: not encapsulated infiltrative neoplastic proliferation of round vacuolated cells. The atypical manifestation of cutaneous metastasis and mainly pulmonary metastasis, in this case, denote the importance of TVT inclusion as a differential in cutaneous neoplasia, even if they show distant organ metastasis. Therefore, it emphasised the importance of cytology and histology in the diagnosis of nodular affections.
\end{abstract}

KEYWORDS: Canine, Cancer, Pharynx, Cutaneous Tumour.

\begin{abstract}
RESUMO: O tumor venéreo transmissível (TVT) é uma das neoplasias mais frequentes em cães. Com características específicas, esse tumor é exclusivo da espécie canina. Sua transmição acontece através da transplantação de células neoplásicas viáveis quando em contato com mucosas ou pele não íntegra, raramente ocorrendo metástases. Este trabalho visa relatar a apresentação rara de metástase pulmonar de tumor venéreo transmissível generalizado em um cão Blue Heeler. O paciente apresentava-se caquético, dispneico, desidratado e com diversas nodulações cutâneas e em faringe. A citologia de todas as nodulações cutâneas evidenciaram células redondas vacuolizadas, com núcleo excêntrico grande e cromatina frouxa, compatível com as características microscópicas de TVT. Em decorrência da evolução clínica e prognóstico reservado, o paciente foi eutanasiado. No exame macroscópico foi evidenciado massa em lobo caudal do pulmão direito com as mesmas características histopatológicas dos demais nódulos, proliferação neoplásica de células redondas vacuolizadas infiltrativas não encapsuladas. A manifestação atípica de metástases cutâneas e principalmente pulmonar neste caso denota a importância da inclusão do TVT como diferencial de neoplasias cutâneas mesmo com metástase em órgãos. Com isso ressalta-sea importância de exames de citopatologia e histopatologia no diagnóstico de afecçóes nodulares.
\end{abstract}

PALAVRAS-CHAVE: Canino, Câncer, Faringe, Tumor cutâneo, Nódulo ulcerado, TVT.

\section{INTRODUCTION}

The canine transmissible venereal tumour (TVT) is a canid exclusive prevalent neoplasia (GANGULY; DAS; DAS, 2016). Its transmission occurs through viable neoplastic cell transplantation in contact with injured skin or mucosa. The main presentation is the genital form, which is transmitted by coitus. In males, the tumour is usually implanted at in the caudal part of the penis near the bulb, on the glans, and in the foreskin occasionally (SETTHAWONGSIN et al.; 2019; UÇAR, 2016).

The clinical presentation of lesions may vary from a single mass to a multilobular mass cauliflower-like aspect (UÇAR, 2016). Generally, the mass is friable spoliative and ulcer easily (GANGULY; DAS; DAS, 2016). The signs observed are 
commonly subtle when there is no apparent mass featuring continuous bleeding; frequently it is confused with the persistence of oestrus or haematuria. TVT can manifest as intermittent or persistent ulcerated lesions. Animals may have swelling of the affected area and constant licking of the region (KOMNEOU et al., 2015).

TVT is diagnosed after a judicious physical examination in addition to the clinical manifestation and the cytological and histological results (SETTHAWONGSIN et al., 2019; UÇAR, 2016). Cytologically, TVT is seen as a malignant round cell tumour that can be classified as plasmacytoid, lymphocytoid, or mixed according to its cell particularities. The plasmacytoid type is related to an increase in malignancy and poor chemotherapy response, and it is more often found in extragenital forms (GONZALEZ et al., 2000; OJEDA et al., 2018).

Neoplastic development can be rapid, aggressive, and oftentimes fatal especially in puppies due to immunosuppression or when it is accompanied by concomitant diseases. These tumours regress spontaneously in immunocompetent dogs after a controlled clinical growth, when a certain degree of immunity mediated by type $\mathrm{G}$ immunoglobulins can be developed (GANGULY; DAS; DAS, 2016; UÇAR, 2016).

Metastasis occurs in less than $10 \%$ of cases and is associated with immunocompromised animals or at a mechanic extension of the tumour (PINCZOWSKI et al., 2015). The most common metastasis formation spot is on the regional lymph nodes; however, distant manifestations of the primary focus have already been documented as in the skin, kidney, spleen, liver, eye, and brain (KOMNENOU et al., 2015; UÇAR, 2016). Males demonstrate a higher percentage of metastasis than females (AHUJA et al., 2017).

In this study, we report a rare manifestation of TVT in an intact dog with cutaneous nodulations and an isolated pulmonary nodule without any manifestations in the genitals.

\section{CASE REPORT}

An adult Blue Heeler dog was attended to a veterinary school hospital due to wounds in the trunk and right pelvic limb. The animal was rescued and did not have a reported clinical history.

On physical examination, the dog showed inspiratory and dizzying dyspnoea, cachexia, dehydration (8\%), hyperthermia $\left(39,8^{\circ} \mathrm{C}\right)$, pale mucous membranes, and multiple round nodulations in the pharynx area (Figure 1). The patient's age was estimated to be between 8 and 10 years, according to the dental arch.

An ulcerated mass of about $10 \mathrm{~cm}$ at the left shoulder blade and an ulcerated wound in the patellar region of the right posterior limb with raised edges and approximately $4 \mathrm{~cm}$ were noted; both ulcerations were infested with myiasis larvae and had a haemorrhagic purulent secretion. Other circumscribed firm cutaneous nodules were found in the ventral and dorsal regions, trunk, and posterior left limb; they vary

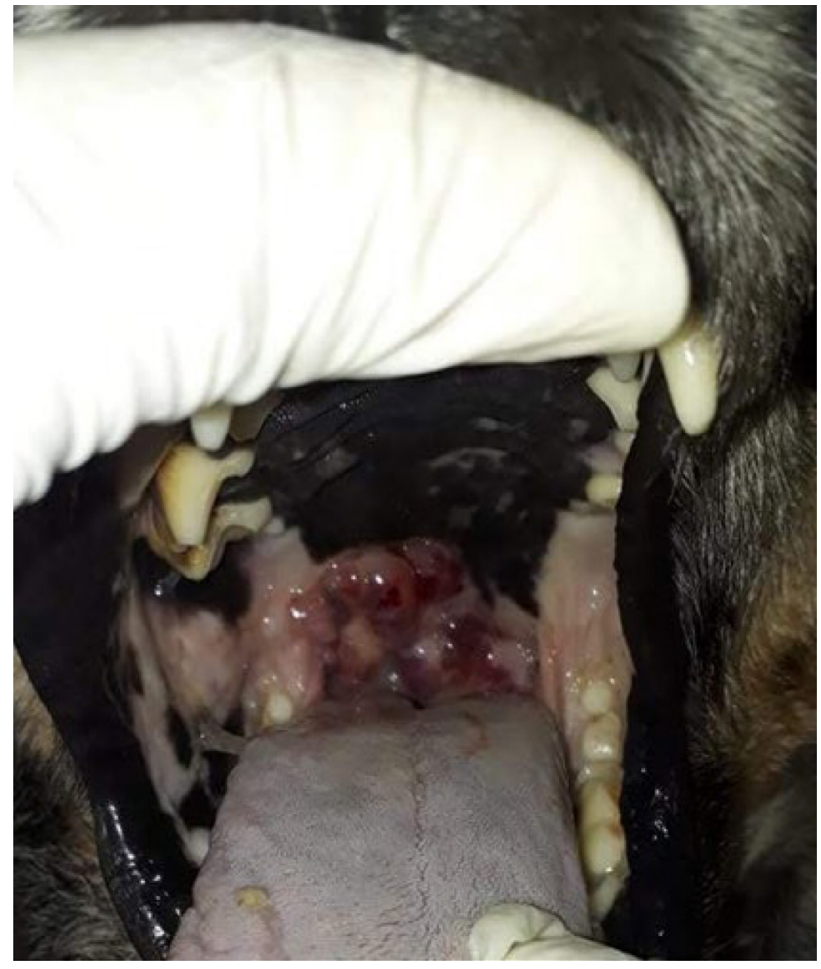

Figure 1. Pharynx transmissible venereal tumour nodulations in a Blue Heeler dog.

from $0,5-3 \mathrm{~cm}$ in diameter without ulceration or adherence and had no colour alterations (Figure 2). Neither lesion was found in the genital region.

The treatment was instituted with Ringer lactate fluid therapy at $30 \mathrm{~mL} / \mathrm{h}$ infusion supplemented with a vitamin compound (bionew- $0.2 \mathrm{~mL} / \mathrm{kg}$ ); antibiotic therapy was made using enrofloxacin $(10 \mathrm{mg} / \mathrm{kg} \mathrm{q} 24 \mathrm{~h})$ associated with metronidazole (20 mg/kg q $12 \mathrm{~h}$ ) and cephalothin ( $25 \mathrm{mg} / \mathrm{kg} \mathrm{q} 12 \mathrm{~h})$; additionally, gradual introduction of food was implemented. Nitenpiram was administered $11.4 \mathrm{mg}$ in a single dose, and the wound was cleaned twice a day with the application of ointment composed by gentamicin $0.5 \mathrm{~g}$; Sulfanilamide $5 \mathrm{~g}$; Urea 5g; Vitamin A 120,000 IU in $100 \mathrm{~g}$ excipient. Omeprazole $(1 \mathrm{mg} / \mathrm{kg} \mathrm{q} 24 \mathrm{~h})$ and ondansetron $(0.2 \mathrm{mg} / \mathrm{kg} \mathrm{q} 8 \mathrm{~h})$ were added to the protocol due to the emesis presented during hospitalisation. On the second day of hospitalisation, the respiratory and gastrointestinal status of the patient worsened.

Haematological analysis revealed normocytic normochromic anaemia (Ht 29\%, MCV 66 fl, MCHC 35\%) with some codocytes and showing leukocytosis (31,400 leukocytes/ $\mu \mathrm{L})$ due to neutrophilia $(27,318)$ and monocytosis $(4,082)$. Hyperproteinaemia due to hyperglobulinemia with hypoalbuminemia was also found in biochemical analysis. There were no alterations in thoracic radiography, abdominal ultrasonography, or other biochemical examinations.

Cytological examination of all cutaneous lesions revealed high sampling cellularity, predominating neoplastic cells with an eccentric nucleus and abundant vacuolated cytoplasm 


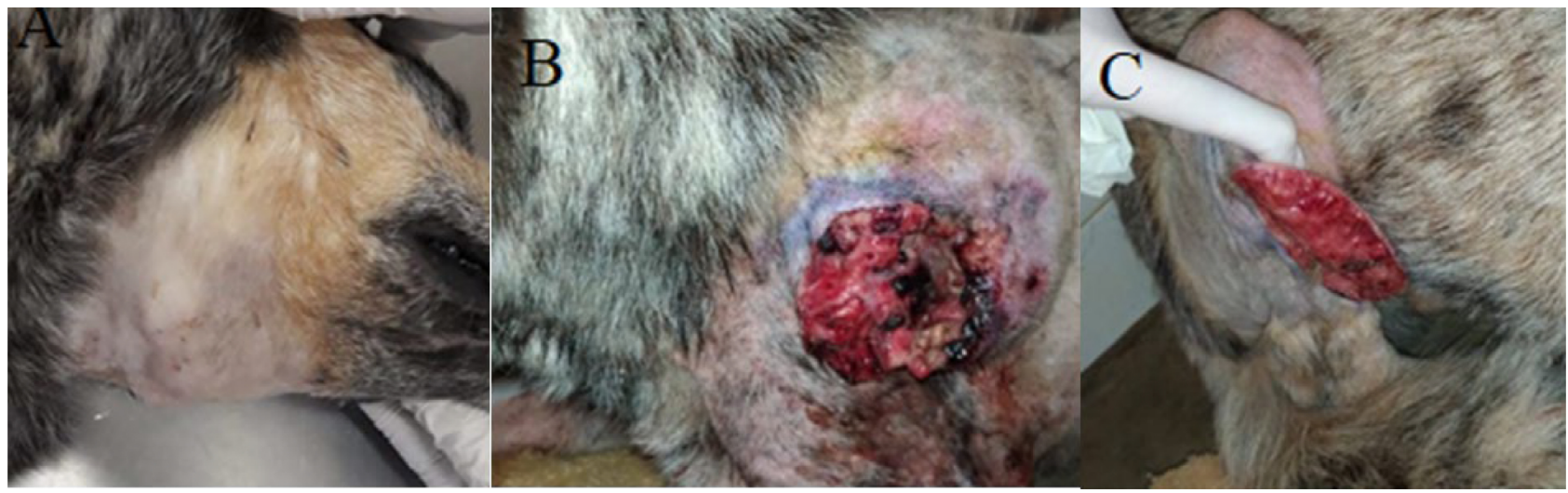

Figure 2. Multiples lesions of transmissible venereal tumour in a Blue Heeler dog. (A) Ventral cutaneous nodulations. (B) Left shoulder blade ulcerated nodulation. (C) Right posterior limb nodulation.

associated plasmacyte cells. These attributes were compatible with the plasmacytoid type of transmissible venereal tumour. Due to the worsening of the clinical state and a preserved prognosis, the patient was euthanized.

Necroscopic examination allowed observation of the soft palate mass extension; it was multinodular and stayed in soft palate to the larynx. The mass had a firm consistency and irregular reddish surface. On the pulmonary left medial lobe, there was a focal adherence area between the visceral pleura and parietal pleura adjacent to the rib. Signs of pulmonary emphysema in the right lung were also observed. Furthermore, a reddish firm mass at right pulmonary caudal lobe was found measuring $1.8 \times 2.1 \mathrm{~cm}$ projecting over the pleural surface and bounded by a red halo (Figure 3 ). Myxomatous degeneration was noted in the mitral valve and chronic glomerulonephritis in the kidneys.

Histopathologic analysis of cutaneous, oral, and pulmonary nodulations (Figure 4) showed high cellular neoplastic proliferation of round infiltrative cells well grouped in a solid mantle arrangement, separated from the pulmonary tissue by a thin fibrovascular stroma. The cells were well delimited and had an eosinophilic cytoplasm, sometimes vacuolated, with a large round eccentric nucleus. Chromatin ranged from finely dotted to lose, showing evident nucleoli often multiple and presence of more than one mitosis figure per field of high magnification. The diagnosis was compatible with TVT.

\section{DISCUSSION}

TVT is a common occurrence of neoplasia in unneutered stray dogs at a fertile age with genital manifestation predominating in young adult dogs and extragenital form in older dogs and puppies (GANGULY; DAS; DAS, 2016). This study reports the manifestation of TVT in an adult senile dog, which owing to its health condition allowed the development of extragenital metastatic TVT. It is proposed that the atypical manifestation is associated with a poor host immune response to tumour proliferation. In addition, comorbidities such as mitral valve myxomatous degeneration and glomerulonephritis may have contributed to

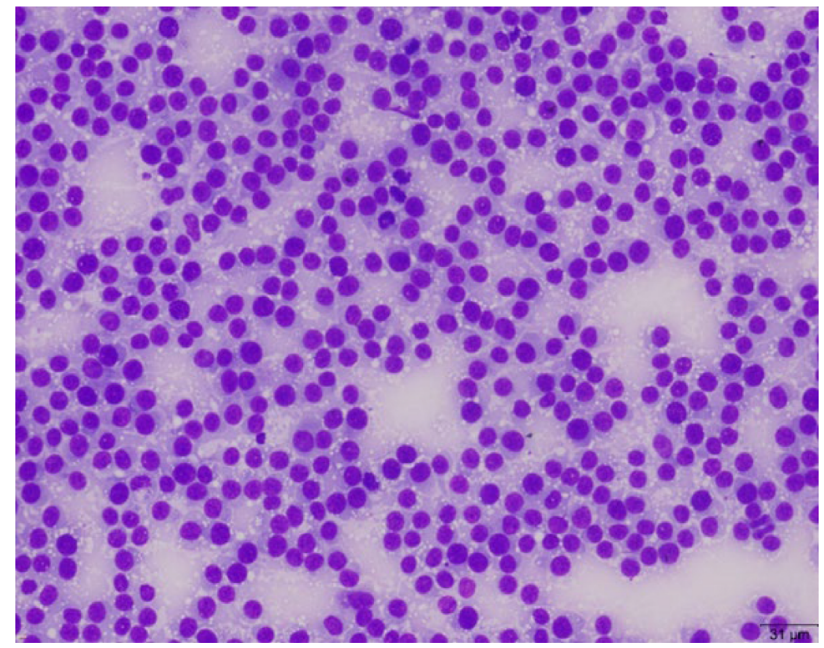

Figure 3. Cytology of isolated paravertebral nodule of transmissible venereal tumour in a dog showing high cellularity of round neoplastic cells compatible with the plasmacytoid type.

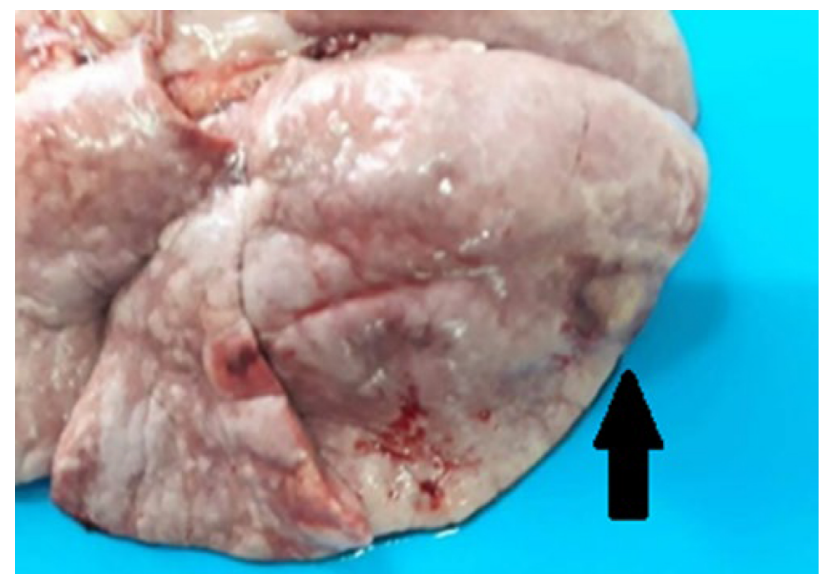

Figure 4. Isolated metastatic nodule of the transmissible venereal tumour (black arrow) into the right caudal lung in a dog.

the spread of the disease (OJEDA et al., 2016; PINCZOWSKI et al., 2015). Additionally, immunosuppression is a fundamental factor for the occurrence of lymphatic and/or blood metastases (OJEDA et al., 2016; RAMOS et al., 2019). 

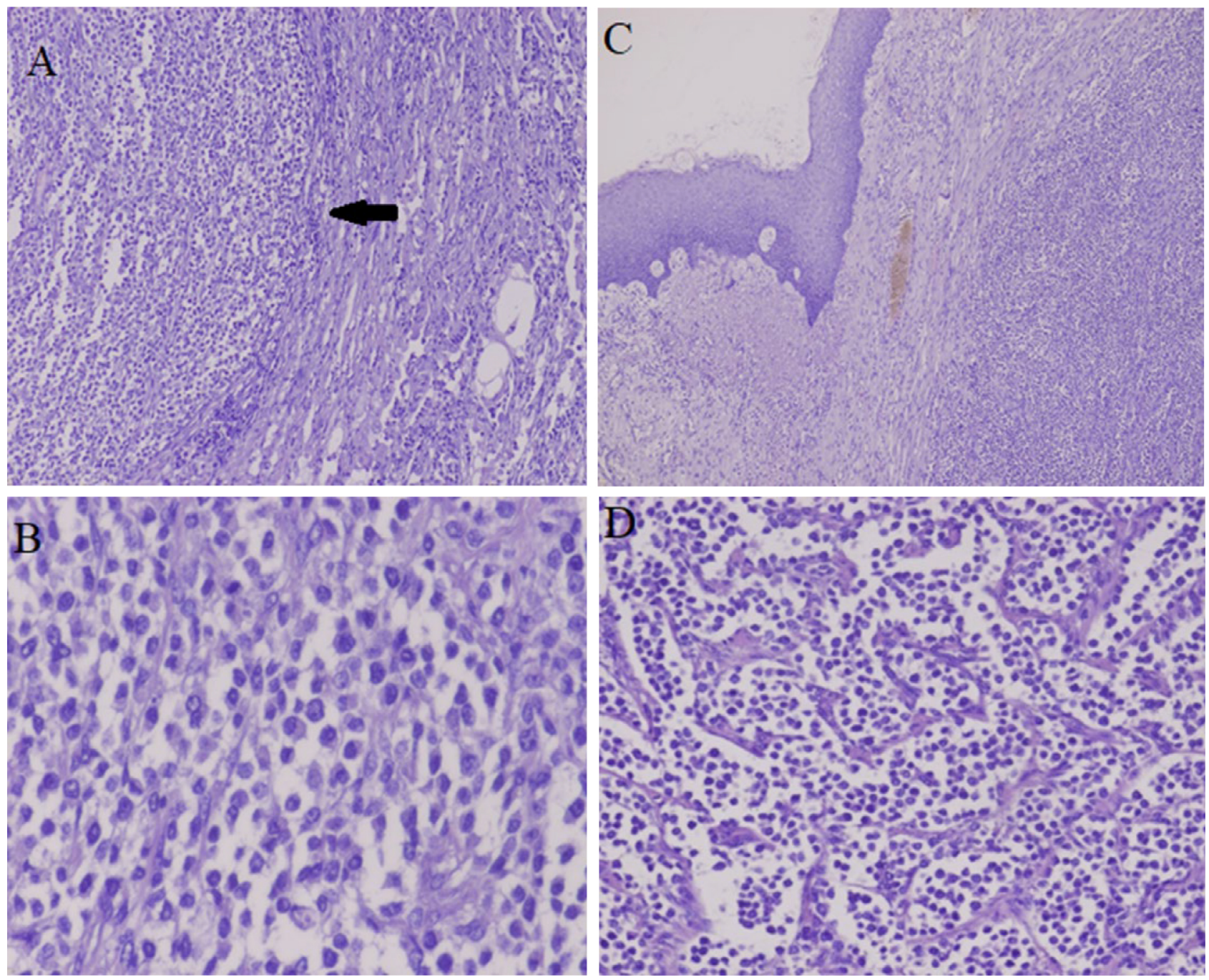

Figure 5. Histological sections images in HE staining of the pharynx and lung dog nodule. (A) Lung in 15x magnification showing neoplastic nodule wrapped in a thin fibrovascular stroma (black arrow) compressing lung parenchyma. (B) Pulmonary TVT nodule with 40x magnification revealing round cells with eosinophilic cytoplasm and large rounded eccentric nucleus. (C) Pharynx in 4.2x magnification with poorly demarcated, non-encapsulated neoplastic infiltration. (D) Nodulation of TVT in the pharynx with 15x magnification, exposing well-rounded cells arranged in a mantle.

The exclusively extragenital form of firm nodule consistency, where it is not friable or has an exophytic growth is typically described for this tumour. The clinical diagnosis was made through cytopathological examination and histopathological analysis, which showed the presence of characteristic neoplastic cells of the lesions. One way to differentiate TVT from other round cell tumours is through cellular markers, such as vimentin, lysozyme, alpha-antitrypsin (MAHDIEH et al., 2016; PEREIRA et al., 2000); however, in our case, both cytological and histopathological aspects were sufficient to confirm the diagnosis.

The cellularity observed on cytology demonstrated a plasmacytoid pattern frequently related with an aggressive, more invasive, and chemotherapy-resistant form, with the pattern being the most common in extragenital formations (GONZALEZ et al., 2000; OJEDA et al., 2018; OJEDA et al., 2016). Moreover, there were any regression marks, such as lymphocytic infiltration, necrosis, or tumour apoptosis (BONILLA et al., 2015; OJEDA et al., 2016).

TVT extragenital forms are often restricted to a single anatomical region, as the face and mouth make a definitive diagnosis when multiple areas are affected. This fact leads to the erroneous diagnosis of other round cell neoplasms such as plasmacytoma, histiocytoma, and mastocytoma (RAMOS et al., 2019; SINGH; SOOD, 2016; TANNOCK et al., 2013). In this patient, it is believed that nodulations in the oral cavity occurred probably due to cell transplantation induced by licking of the existing neoplastic lesions in the scapula and pelvic limb.

Tumour migration to distant foci can occur as a result of tumour cells passing into circulation, mainly because the tumour vessels are less organised and more 
permeable compared to physiological ones (BATSON, 1940; RAMOS et al., 2019; SINGH; SOOD, 2016). It is assumed that a tumour cell embolus reaches the capillary bed and is drained into the vena cava and ends into the lungs (BATSON, 1940; FONSECA et al., 2020; OJEDA et al., 2018). We cannot exclude the possibility of tumour cell aspiration by the oral mass; however, aspirated particles tend to be located in the anteroventral and non-caudal lobes, as observed in this patient (AYSAT et al., 2018; BONILLA et al., 2015; RAMOS et al., 2019). The nodule was not seen on radiographic examination because of its anatomical location, which generates overlapping structures of the same density.

The formation of the emboli also supports the presence of disseminated subcutaneous nodulations, which instead of following the main circulation through the vena cava, was spread through the vertebral vascular plexus being retained in cutaneous capillaries (BATSON, 1940; TANNOCK et al., 2013). This path of the vertebral plexus connects with the cerebral and ocular vasculature, already reported as metastasis points for TVT (KOMNENOU et al., 2015; PEREIRA et al., 2000; PINCZOWSKI et al., 2015).

Lymphatic metastasis is commonly reported in TVT cases. Satellite lymph nodes are primarily affected, and the progression of the neoplasm occurs more slowly when compared to the hematogen pathway. One route of metastasis does not exclude the possibility of the other (BATSON, 1940; TANNOCK et al., 2013). However, no macroscopic or microscopic changes were observed in the lymph nodes of this animal, suggesting that metastasis occurred via hematogen, without excluding the oral mass as the primary tumour site.

A greater malignancy compared to other karyotypes was associated with the manifestation seen at the transmissible tumour of Tasmanian demons, which predominantly affects the face, neck, and oral cavity and frequent development of lung metastasis that evolves to death a few months after the signs of clinical onset (OSTRANDER; DAVIS; OSTRANDER, 2016; PELL; BELOV, 2016).

TVT prognosis is good when the patient does not have concomitant diseases, immunosuppression, or severe malnutrition that impair its response to necessary therapies (AYSAT et al., 2018; FEGHIU et al., 2015). Chemotherapy is an effective treatment that leads to total tumour remission and complete recovery without evident reproductive sequelae (DALECK et al., 2018). Chemotherapy was not instituted in this case due to the advanced presentation of neoplasia and poor prognosis.

\section{CONCLUSION}

Canine transmissible venereal tumours are mainly related to neoplasms in the genital regions of dogs. Due to atypical presentations, such as the one presented in this report, the appearance of new dissemination forms or changes in the behaviour of this tumour type could be confirmed. TVT should be considered in differential diagnoses for cutaneous neoplasms and those with metastases in the respiratory tract or abdominal organs. Careful examination and intensive care are recommended in immunosuppressed patients, who are predisposed to the atypical and most malignant forms of this tumour.

\section{REFERENCES}

AHUJA, $A$. et al. Cutaneous and genital form of canine transmissible venereal tumour: A rare case. Indian Veterinary Journal, v. 94, p. 62-63, 2017.

AYSAT, A. et al. Metastatic transmissible veneral tumour in a twelveyear-old castrated local dog. Alexandria Journal of Veterinary Sciences, v. 61, p. 1-6, 2018.

BATSON, O. V. The function of the vertebral veins and their role in the spread of metastases. Annals of Surgery, v. 112, n. 1, p. 138$149,1940$.

BONILLA, F.T. et al. Reporte de caso: tumor venereo transmisible en perro mestizo. REDVET, v. 16, n. 1, 2015.

DALECK, C.R. et al. Utilização da doxorrubicina e ciclofosfamida no tratamento do tumor venéreo transmissível canino intranasal: relato de caso. A Hora Veterinária, v. 164, n. 28, p. 58-61, 2018.

FEGHIU, A. et al. Nasal transmissible venous tumour in A Jack Russel Terrier Bitch. Acta Veterinaria, v. 65, n. 1, p. 143-148, 2015.
FONSECA, L. S. et al. Spontaneous canine transmissible venereal tumour: association between different phenotypes and the insertion of LINE-l/c-myc. Revista Colombiana de Ciências Pecuárias, v. 25, п. 3, p. 402-408, 2020

GANGULY, B.; DAS, U.; DAS, A. K. Canine transmissible venereal tumour: a review. Vet Comp Oncology, v. 14, n. 1, p. 1-12, 2016.

GONZALEZ, C.M. et al. Canine transmissible venereal tumour: a morphological and immunohistochemical study of ll tumours in the growth phase and during regression after chemotherapy. Journal of Comparative Pathology, v. 122, n. 4, p. 241-248, 2000.

KOMNENOU, A.T. et al. Ocular manifestations of canine transmissible venereal tumour: a retrospective study of 25 cases in Greece. Vet Record, v. 176, n. 20 p. 523, 2015.

MAHDIEH, R. et al. Primary oral and nasal transmissible venereal tumours in a mixed-breed dog. Asian Pacific Journal of Tropical Biomedicine, v. 6, n. 5, p. 443-445, 2016. 
OJEDA, J. et al. Tumour venéreo transmisible diseminado sobre piel, párpados y pene en un perro: Reporte de caso. Archivos de Medicina Veterinária, v. 48, n. 1, p. 119-123, 2016.

OJEDA, J. et al. Computer tomographic imaging of 4 dogs with primary nasal canine transmissible venereal tumour and differing cellular phenotypes. Journal of Veterinary Internal Medicine, v. 32, p. 1172-1177, 2018.

OSTRANDER, E. A.; DAVIS, B.W.; OSTRANDER, G. K. Transmissible Tumours: Breaking the Cancer Paradigm. Trends in Genetics, v. 32, n. 1, p. 1-15, 2016.

PEEL, E.; BELOV, K. Lessons learnt from the Tasmanian devil facial tumour regarding immune function in cancer. Mammalian Genome, v. 29, p. 731-738, 2018.

PEREIRA, J. S. et al. Immunohistochemical characterisation of intraocular metastasis of a canine transmissible venereal tumour. Veterinary Ophthalmology, v. 3, p. 43-47, 2000.

PINCZOWSKI, P. et al. Brain metastasis in a case of canine transmissible venereal tumour after a supposed successful treatment with vincristine sulphate. Acta Veterinaria Beograd, v. 65, n. 1, p. 137-142, 2015.

RAMOS, J.N. et al. Tumour venéreo transmissível cutâneo sem envolvimento genital em cão macho. Veterinária e Zootecnia, v. 26, p. 1-6. 2019.

SETTHAWONCSIN, C. et al. Conventional-vincristine sulphate vs. modified protocol of vincristine sulphate and L-asparaginase in canine transmissible venous tumour. Frontiers in Veterinary Science, v. 6, p. 300, 2019.

SINGH, R.; SOOD, N. Management of primary transmissible venous tumour in nasal cavity of a dog. Intas Polivet, v. 17, p. 546-548. 2016.

TANNOCK, I.; HILL, R.; BRISTOW, R.; HARRINGTON, L. Basic Science of Oncology. 5. ed. US: McGraw-Hill Professional, 2013, 592p.

UÇAR, M. Transmissible Venereal Tumor: A Review. Kocatepe Veterinary Journal, v. 9, p. 230-235, 2016. 